\title{
Practice of Life-oriented Network Ideological and Political Education Based on Mobile APP
}

\author{
Meijun Ding ${ }^{1}$, Zhiqiang Mao ${ }^{1}$, Wen Zheng ${ }^{1}$ \\ ${ }^{1}$ College of Marxism, Yunnan University of TCM, Kunming, 650500, China
}

Keywords: Ideological and political education, Mobile APP, Mobile internet

\begin{abstract}
To enhance the affinity and pertinence of ideological and political work in colleges, it is necessary to start from the daily life of college students to find the breakthrough point with ideological and political education, and let ideological and political education run through student's daily life practice. The rapid development and popularization of smart phones have brought new opportunities and challenges to the ideological and political life education practice in colleges. This paper puts forward the suggestions of increasing development efforts, improving content construction and strengthening campus promotion to provide some references for the ideological and political teachers in colleges and universities.
\end{abstract}

\section{Introduction}

Ideological and political education in daily life is not simply return to the theoretical level of scientific interpretation to form a correct goal, content, path, method, to enhance the effectiveness [1]. To explore the theoretical basis of Ideological and political education of college students in a comprehensive and in-depth way, through the analysis of these theories, to explore the theoretical basis of Ideological and political education of college students in life to clarify the theoretical basis of Ideological and political education of college students in life. The goal of Ideological and political education in China expresses people's expectations for a better future, but at present China is still the largest developing country in the world. Although people's living standards have been greatly improved, people's overall cultural level is not too high, and their ideological awareness is uneven, which is different from the current people's culture and consciousness. There is still a far cry from the level of understanding. Therefore, the goal seems too idealistic, specific implementation will appear to be some hollow, not easy for people to make accurate positioning of their specific behavior. In people's daily life and the state's mainstream media propaganda, ideological and political education is often positioned as the goal of selfless spirit, the best personality, and so on, while the ordinary people around to do a bit of good things are difficult to show examples in the mainstream media. In view of the above reasons, the necessity of Ideological and political education is highlighted. Life-oriented ideological and political education is to make all kinds of Ideological and political education activities close to the reality of people's lives to avoid the idealized state of confining theory to the ivory tower. The high goal will make the ideological and political education deviate from the people's life field and the people's life state [2].

\section{Problems faced with Life-oriented Network Ideological and Political Education Based on Mobile APP}

\subsection{Insufficient Application Understanding}

At present, the ideological and political educators have a certain lag in the face of new media, and do not have the sensitivity to control information, just realized the importance of Wechat, Weibo, has not taken into account the potential role and value of campus APP; some schools do not have an official APP, there is no corresponding rules and regulations for the management of APP students 
develop, resulting in The school information released by the existing APP is lack of authority, and there are a lot of false, fraud, pornography, violence and other content, the excessive publicity of management backstage also leads to the risk of student information security increases; some schools have developed APP, but the function is single, the style is simple, the speed of information change is slow, the developer is not ideological and political education. The content of Ideological and political education cannot be effectively linked with the APP function development; while the ideological and political educators know less technology, usually to deal with heavy business work and various platforms of information maintenance, no time to develop and operate campus APP. Student's study life takes various academic activities as its manifestation. Spending such study life enriches student's life meaning and value pursuit. Learning lifestyle is a special way of life for college students, which highlights the living conditions accompanied by experience in academic activities. Although ideological and political education is theoretically strong, some abstract and empty language indoctrination education makes some students not accept ideological and political education cognitively and reject it psychologically. The content of Ideological and political education which is concrete, life-oriented and close to ideological and political reality is obviously weak, and the ways and learning of Ideological and political education are obvious. Lifestyle mismatches, fails to serve the actual effectiveness of student life, to a certain extent, deviates from the original intention of education returning to life [3].

\subsection{Low Content Attraction}

As the carrier of Ideological and political education, all need to load the ideological and political education information, this information is often not intuitive and explicit, but accept information in the process of receiving the guidance of the organizers and jointly participating. Through the investigation and study of the current campus APP, it is found that most campus APPs mainly provide school news information, obtain lecture information, understand the allocation of study rooms, view the campus map, study, life, leisure services. Although there is a huge amount of information, these contents cannot become the resources of Ideological and political education, even if there are. The campus APP set up the ideological and political section, but also simply copy the traditional ideological and political education content, the content is boring and obscure, and cannot be closely linked with the ideological of college students, excessive restriction and blockade of the content of the social section, resulting in students cannot express their views to vent their emotions, making many early developments very hot. The explosive campus APP gradually lost its appeal. The contents of college students' network ideological and political education are fragmented and diversified. College student's learning styles and thinking habits are fragmented in cyberspace, which makes it difficult to form a personal systematic and logical knowledge system. How to highlight the important role of social mainstream ideology in the mass of Internet information content for college student's ideology, and at the same time to provide ideological and political education for college students in line with social requirements and development laws, college students like to see, meet the needs of Internet communication has become a prominent problem. The traditional ideological and political education is based on the propaganda context of the government or colleges and universities, which plays an important role in the ideological and political education of College students. The content of Ideological and political education should be more in line with the psychological characteristics and cognitive styles of college students [4].

\subsection{Inadequate Promotion Effort}

Campus APP as a carrier of Ideological and political education, the main advantage is the timeliness and interaction, which requires educators to invest a lot of time and energy to select the appropriate information, and according to the characteristics of mobile phone set activities, to write attractive, students are willing to accept the content. At the same time, it is also necessary to keep the interaction with students, answer the feedback of students in the campus APP timely, and collect, classify, summarize, guide and dredge public opinion, which also requires a strong sense of responsibility. However, there are few ideological and political educators who develop and manage 
campus APP full-time with new media technology. Ideological and political educators have no time to use it objectively and subjectively in their daily work, especially campus APP, which is a carrier with strong instantaneity and interaction. Educational media play a bridge and link role between the various elements of educational activities, profoundly affecting the depth and breadth of educational activities, directly restricting the development of educational organizational forms and educational methods. As far as the environment of the educational object is concerned, the educator is not only a university, but also the educational medium will go beyond the narrow scope of intermediary, even including the family, society and other educational environment which exerts influence on the educational object. From the perspective of the evolution history of educational media, every development of educational media will lead to changes in the form of educational organization and mode of education. The emergence of printing media has made human education scale. With the wide application and popularization of digital media, educational forms have become richer and more diversified. Class teaching and decentralized learning coexist, school education and network teaching coexist, and educational carriers are increasingly diverse. Emerging media has become an integral part of education.

\section{Optimization Paths of Network Ideological and Political Education Based on Mobile APP}

\subsection{Increase Development Efforts}

Ideological and political educators should always maintain a high degree of sensitivity and openness, break the thinking set, fully realize the extreme importance and practical urgency of APP in the field of Ideological and political education development and application. At the same time, we should grasp the path and technology of the development of APP carrier for ideological and political education, and strive to develop special APP software for ideological and political education, or infiltrate the content of Ideological and political education into the existing relevant educational software. Therefore, it is urgent for ideological and political education workers to actively participate in network technology training, master programming language and data analysis technology, and improve their own application and program development capabilities. Work closely with the APP development team and make use of their professional advantages to provide technical support for the development and operation of APP for college ideological and political education. College students are encouraged to develop innovative spirit and independently develop APP carriers related to ideological and political education teaching, management and scientific research. In a word, the ideological and political education workers should set up the development consciousness and innovative thinking, develop the APP carrier which covers a wider range, carries more ideological information, is more convenient to operate, and is more characteristic. This is not only the response of Ideological and political education to the severe challenges of the mobile Internet era, but also the enrichment and development of Ideological and political education. The necessary requirement of the carrier.

\subsection{Improve Content Construction}

By collecting the latest life trends of students, integrating positive ideological content inside and outside the network, and making use of all opportunities and conditions to coordinate and cooperate with each other to form the communicative resultant force of Ideological and political education, the ideological and political education content interweaves with the daily life of College students, goes hand in hand, and constantly advances the construction of new media propaganda position for ideological and political education in colleges and universities. Set up to seize the commanding heights of campus network and create a positive campus network culture atmosphere. Only when the content of Ideological and political education arouses the interest of college students can the attraction and user stickiness of campus APP be strengthened. To ensure the effective use of Ideological and political education function of campus APP, we must process the information carried by it to avoid hard and boring information occupying the main page for a long time. Mobile phone 
culture can provide a kind of campus APP for college students. The feeling of the combination of pictures and text, voice and emotion make the content of ideological and political education in colleges and universities more vivid and interesting, which makes it convenient for college students to study and sublimate their ideas. We can aggregate the content that college students like to see and hear, push the hot issues of micro-mail, micro-blog, campus local, and show the content of Ideological and political education through pictures, micro-videos and other multimedia forms, respect interests and hobbies, give full play to students' creativity and originality, and encourage students to publish news in campus APP. Create an atmosphere, show individuality and show yourself. In the construction of campus APP, fashion, entertainment and modern elements are often adopted to give full play to the characteristics of implicit education, consciously cultivate many opinion leaders, infiltrate educational information into local information close to the interests of students, such as examination information, employment information, academic lectures, campus entertainment news, etc., and give full play to the advantages of peer education. Campus APP can set up its own sections and push information at will. It can not only push short messages, but also push long articles, videos and voice. It can also aggregate Internet resources. It can also set up content according to the actual situation.

\subsection{Strengthen Campus Promotion}

Carrier is to be able to contact the subject and object of education, so that each student uses campus APP to play the role of campus APP education. Therefore, to promote the development and operation of campus APP, we can publish the traditional QQ, WeChat and website information to campus APP in a unified way to avoid the distraction of College students. Through the integration of educational administration system, we can also set up part of the content of Ideological and political education in campus APP. Students must be in campus A. To get the course examination, we can complete the corresponding content in PP. In addition, the stable operation and mature management of campus APP can be commercially promoted, the introduction of e-commerce cooperation will expand the influence of campus APP, thus carrying more forms of Ideological and political education content. The orientation of educational goal should be based on reality and not be too high, so that it can be separated from the masses. This will not only cause the waste of educational resources, but also make the actual results of ideological and political education have little effect, and even increase the rebellious psychology. The formulation of Ideological and political education goals in line with the actual needs of Ideological and political education has become a powerful booster for the implementation of life-oriented ideological and political education. First, the educational goal should be close to life, realize the transformation from ideal to reality, make the ideological and political education goal fall back to reality, and change the few people targeted by the educational goal into most ordinary people. Their ideological dynamics and moral cultivation are related to the level of social development, social stability and historical development. The formulation of goals should reflect hierarchy. The hierarchy of Ideological and political education goals refers to the determination of different ideological and political education goals in the practice of Ideological and political education according to the status quo of different levels of people.

\section{Conclusion}

The ideological and political education is not a theoretical system of nothing but a scientific system which comes from life and can successfully restrain and guide people to love society, abide by discipline and law, and discover truth, goodness and beauty. As the main body of Ideological and political education, educators should play a positive role in guiding the use of mobile APP and other advanced technology to guide college student's life. 


\section{References}

[1] Zhou Qi. On the Formation, Life form and Conscious Practice of Ideological and Political Education Environment [J]. Teaching and Research, 2017(10): 89-93.

[2] Chen Wenliang, Du Lijuan. Dilemma and Breakthrough: An Analysis of Effective Ways for University Students'Network Ideological and Political Education under the Micro-Life Normal [J]. Journal of Jimei University, 2017, 18(6): 58-63.

[3] Zou Yanhui. Effect of College Ideological and Political Education Integrated in Daily Life [J]. Journal of Yangzhou University (Higher Education Study Edition), 2014, 18(5): 51-54.

[4] Zhang Yuan, Wang Cui. Study on the Integration Ideological and Political Education of College Students via Internet into Daily Life [J]. Meitan Higher Education, 2015, 33(4): 35-38. 